ЛАВРОВА О. А.

СОДЕРЖАНИЕ ПРИОРИТЕТНЫХ ЦЕННОСТЕЙ У ВОЕННЫХ И ГРАЖДАНСКИХ ПЕНСИОНЕРОВ...

РосСиЙский психологИчЕСКИй жУРнАл, 2019, Т. 16, № 4, 42-55. doi: 10.21702/rpj.2019.4.4

ОБЩАЯ ПСИХОЛОГИЯ, ПСИХОЛОГИЯ ЛИЧНОСТИ, ИСТОРИЯ ПСИХОЛОГИИ

УДК 159.9.072.43 doi: $10.21702 /$ rpj.2019.4.4

Оригинальная научная статья

\title{
Содержание приоритетных ценностей у военных и гражданских пенсионеров с разными уровнями самоактуализации
}

\author{
Ольга А. Лаврова \\ Кубанский государственный университет, г. Краснодар, Российская Федерация \\ E-mail: lavloa@yandex.ru \\ ORCID: https://orcid.org/0000-0002-7341-3653
}

\begin{abstract}
Аннотация
Введение. В статье отмечен исследовательский интерес к проблематике ^ичностных ценностей применительно к позАним периоАам онтогенеза ^ичности. В контексте субъектного по Ахо Аа автором теоретически обосновывается рассмотрение самоактуализации пенсионера как олного из критериев его аАаптационной готовности к новым Условиям жизнеАеятельности в связи с изменением социального статуса. В работе представлен эмпирический анализ ценностно-смысловых характеристик военных пенсионеров, и проверяется гипотеза об их специфике с учетом уровня самоактуализации пенсионеров.

Методы. В процессе исследования были использованы методика Ш. Шварца Аля изучения ценностей личности и краткая шкала измерения самоактуализации. Объем выборки состави^ 130 человек. Выборка была разделена на основную (65 человек - военные пенсионеры) и контрольную (65 человек - гражАанские пенсионеры).

Результаты и их обсужаение. Специфрика ценностно-смысловой сореры военных пенсионеров была выявлена и описана в статье на основе сравнения с характеристиками ценностно-смысловой сореры гражАанских пенсионеров. В качестве ценностных приоритетов военных пенсионеров эмпирически зафиксированы конфрормность, тралиции и безопасность. В группе гражАанских пенсионеров была зафиксирована большая Аифрференциация инАивиАуальных ценностных выборов респонАентов. По таким ценностным выборам, как в^асть, Аостижение, стимуляция, универсализм, Аоброта, тралиции, конфоормность, были заффиксированы статистически Аостоверные различия межАу респонАентами в основной и контрольной выборках. Самостоятельность выступает в качестве ценностного приоритета и военных, и гражАанских пенсионеров с высоким уровнем самоактуализации. У пенсионеров с низким уровнем самоактуализации ценностными приоритетами выступают власть и стимуляция.
\end{abstract}

\section{КАючевые слова}

ценности, ценностно-смысловая сорера, ценностные приоритеты, пенсионный возраст, военные пенсионеры, гражданские пенсионеры, алаптация, алаптационная готовность, самоактуализация, уровни самоактуализации

\section{Основные положения}

> в качестве специфических ценностных приоритетов военных пенсионеров Аиагностированы конорормность, традиции и безопасность; 
ЛАВРОВА О. А.

СОДЕРЖАНИЕ ПРИОРИТЕТНЫХ ЦЕННОСТЕЙ У ВОЕННЫХ И ГРАЖДАНСКИХ ПЕНСИОНЕРОВ..

РОССИЙСКИЙ пСИХОЛОГИЧЕСКИЙ ЖУРнАл, 2019, Т. 16, № 4, 42-55. doi: 10.21702/rpj.2019.4.4

ОБЩАЯ ПСИХОЛОГИЯ, ПСИХОЛОГИЯ ЛИЧНОСТИ, ИСТОРИЯ ПСИХОЛОГИИ

$\checkmark$ самостоятельность мышления и выборов способов Аеятельности, способность к самоконтролю и самоуправлению Аиагностированы как ценностные приоритеты у пенсионеров с высоким уровнем самоактуализации, независимо от их пенсионного статуса;

$\checkmark$ в ценностной структуре пенсионеров с низким уровнем самоактуализации Аоминируют ценности, реализация которых может быть ограничена в $А$ анный возрастной периол: стрем^ение к Аостижению высокого социального статуса, Аоминирование, стремление к новизне иглубоким переживаниям.

\section{Для цитирования}

Лаврова, О. А. (2019). Содержание приоритетных ценностей у военных и гражданских пенсионеров с разными уровнями самоактуализации. Российский психологический журнал, 16(4), 42-55. doi: 10.21702/rpj.2019.4.4

Дата получения рукописи: 08.10.2019

Дата окончания рецензирования: 19.01.2020 Дата принятия к публикации: 23.01.2020

\section{Введение}

Понятие «ценности» чрезвычайно многообразно и многоуровнево. В зарубежной психологии проблема ценностно-смысловой сферы личности освещена в работах А. Маслоу, Дж. Г. Мида, Г. Олпорта, К. Роджерса, М. Рокича, М. Розенберга, М. Смита, В. Франкла, Э. Фромма, Л. Фестингера, Э. Фэриса, Ф. Хайдера, Э. Шпрангера и др. В отечественной психологии те или иные аспекты проблематики ценностей отражены в работах А. Н. Леонтьева, С. Л. Рубинштейна, Д. А. Леонтьева, М. И. Бобневой, Л. И. Божович, В. В. Водзинской, О. И. Зотовой, В. С. Мухиной и др.

Личностные ценности лежат в основе порождения жизненных смыслов (В. А. Ядов, Б. С. Братусь, Д. А. Леонтьев, А. Г. Асмолов и др.). Ценностно-смысловая регуляция выступает системообразующим фактором, обусловливает личностную самореализацию либо, наоборот, неудовлетворенность процессом и результатами деятельности, утрату жизненных ориентиров, моральные и эмоциональные потери (В. С. Мерлин, С. Л. Рубинштейн). Динамика ценностей отражает изменения смысла жизни личности, происходящие в процессе ее жизненного пути. Изменения жизненных обстоятельств неизбежно влекут за собой переоценку жизненных ценностей, трансформацию и видоизменение смыслов жизни.

Периодом существенных изменений условий существования личности является пожилой возраст. Большинство исследователей позднего периода возрастного развития личности (Э. Эриксон, Б. Г. Ананьев, В. Франкл и др.) связывают его, прежде всего, с переоценкой ценностей и смысла прожитой жизни. Очевиден исследовательский интерес к проблематике ценностно-смысловых характеристик личности в пожилом возрасте (Анцыферова, 2006; Елишев, 2010; Ермолаева, 2002; Ковалева, н.д.; Куруленко, н. д.; Леонтьев, 1996; Мандель, 2015; Сахарова, Уманская и Цветкова, 2016; Соколова и Берецкая, 2017; Стюарт-Гамильтон, 2010; Халина, 2009; Bilsky \& Schwartz, 1994; Jones, Peskin, Wandeler, \& Woods, 2019; Kleineidam et al., 2019; Juang et al., 2018; Löckenhoff \& Rutt, 2017; Borg, Hertel, \& Hermann, 2017).

Ценностные ориентации, наряду с другими составляющими духовного мира людей, такими, как установки, идеалы и др., рассматриваются современными исследователями как компоненты личностных ресурсов адаптации к изменяющимся условиям жизнедеятельности (Вызулина 
ЛАВРОВА О. А.

СОДЕРЖАНИЕ ПРИОРИТЕТНЫХ ЦЕННОСТЕЙ У ВОЕННЫХ И ГРАЖДАНСКИХ ПЕНСИОНЕРОВ...

РосСиЙский психологИчЕСКИй жУРнАл, 2019, Т. 16, № 4, 42-55. doi: 10.21702/rpj.2019.4.4

ОБЩАЯ ПСИХОЛОГИЯ, ПСИхОЛОГИЯ лИЧнОстИ, ИСТОРИя ПСИхОЛОГИИ

и Ясько, 2015; Халфина, 2018; Nikitin \& Freund, 2019; Jones et al., 2019; Teshale \& Lachman, 2016; Stawski et al., 2019).

Ресурс адаптации определяется как качество (-а) субъекта, позволяющее (-ие) ему достигать желаемых результатов посредством актуализации своих потенциальных возможностей. Ценности, как устойчивые личностные образования, определяют и содержание целей адаптации и средства ее достижения. В связи с выходом на пенсию индивид оказывается в новых условиях жизнедеятельности, к которым ему необходимо адаптироваться, в которых важно найти новые смыслы и выработать новые модели поведения, адекватные изменившимся условиям.

В настоящее время появляются новые понятия, раскрывающие пока неизученные аспекты сложного и многопланового феномена психологической адаптации. Одним из таких понятий выступает адаптационная готовность личности - личностное метаобразование, обеспечивающее ее готовность к эффективному взаимодействию с различными динамично изменяющимися средами (социальными, образовательными, профессиональными и др.) в динамичной системе «личность - среда», ее жизне- и конкурентоспособность в современных динамично изменяющихся условиях. Адаптационная готовность трактуется как проявление субъектом своих потенциальных возможностей в процессе испытываемых социальных воздействий (Арендачук, 2013; Григорьева, 2014; Хмелькова, 2017; Шамионов, 2015). Представляется важным понимание личностно-психологических детерминант, определяющих формирование адаптационной готовности пенсионеров к эффективному взаимодействию с изменившейся средой.

В контексте проблематики адаптационной готовности совокупность личностных качеств, обеспечивающих успешность адаптации в различных ситуациях, рассматривается как личностное новообразование, где ценностно-смысловая сфера личности выступает элементом ее структуры (Арендачук, 2013; Хмелькова, 2017; Шамионов, 2015). Исследование личностно-психологических детерминант адаптационной готовности личности в посттрудовой период жизни имеет перспективу, будучи основанным на сложившихся в психологии традициях субъектной парадигмы (Рубинштейн, 2003). Если поздний период жизни, пенсионный возраст рассматривать как период существенных изменений, то пожилой человек, пенсионер выступает в качестве субъекта изменений условий своего бытия. Субъектность личности выступает в качестве уровневого показателя (Рубинштейн, 2003). Это позволяет использовать ее ключевые характеристики, такие как активность, самоопределение, самодетерминация, самоактуализация, саморазвитие, самосовершенствование, для оценки уровня адаптационной готовности личности в ситуациях изменений. В контексте нашего исследования в качестве одного из критериев адаптационной готовности человека пожилого возраста мы рассматриваем уровень его самоактуализации.

\section{Цель исследования}

Целью представленного фрагмента эмпирического исследования является проверка гипотезы о специфике характеристик ценностно-смысловой сферы военных пенсионеров с разными уровнями самоактуализации, выступающей в качестве одного из критериев адаптационной готовности к новой жизненной ситуации, связанной с изменением социального статуса. 
ЛАВРОВА О. А.

СОДЕРЖАНИЕ ПРИОРИТЕТНЫХ ЦЕННОСТЕЙ У ВОЕННЫХ И ГРАЖДАНСКИХ ПЕНСИОНЕРОВ...

РОССИЙСКИЙ пСИХОЛОГИЧЕСКИЙ ЖУРнАл, 2019, Т. 16, № 4, 42-55. doi: 10.21702/rpj.2019.4.4

ОБЩАЯ ПСИХОЛОГИЯ, ПСИХОЛОГИЯ ЛИЧНОСТИ, ИСТОРИЯ ПСИХОЛОГИИ

\section{Методологическая и теоретическая база исследования}

Методологической основой исследования послужили общефилософские принципы единства и взаимосвязи явлений материального и духовного мира, взаимозависимости человека, деятельности, общества; принципы активности, развития, детерминизма, рассматриваемого как зависимость психических явлений от порождающих их факторов.

Теоретическую основу исследования составили отдельные положения: теории деятельности (А. Н. Леонтьев); концепций субъектного (К. А. Абульханова-Славская, А. А. Брушлинский, С. Л. Рубинштейн и др.); субъектно-деятельностного (Е. А. Климов, О. Г. Носкова, Б. А. Ясько и др.); субъектно-бытийного (В. В. Знаков, З. И. Рябикина, Г. Ю. Фоменко и др.) подходов в психологии личности; психологических теорий адаптации (Ю. А. Александровский, Б. Г. Ананьев, Г. А. Балл, Ф. Б. Березин, Б. Г. Бушурова, И. И. Мамайчук, Ю. Л. Неймер, А. В. Петровский, А. А. Реан, С. И. Степанова, М. Г. Ярошевский и др.); концепции адаптационной готовности личности (М. В. Григорьева, Р. М. Шамионов, И. В. Арендачук, А. Р. Вагапова, Л. Е. Тарасова, Е. Е. Бочарова, О. В. Хмелькова и др.); психологии позднего этапа онтогенеза личности (Л. С. Выготский, Б. Г. Ананьев, Л. И. Анцыферова, А. А. Реан, Е. Е. Сапогова, Г. С. Никифоров, Н. Е. Водопьянова, О. О. Гофман, М. В. Ермолаева, О. В. Краснова, Н. С. Пряжников и др.); основные подходы и концепции теорий ценностно-смысловых образований как психологического «ядра» личности (С. Л. Рубинштейн, Д. А. Леонтьев, А. Маслоу, В. Франкл и др.).

\section{Методы}

В ходе исследования была сформирована выборка, в которую вошли 130 респондентов пенсионного возраста, проживающих на территории Краснодарского края и Республики Крым. Совокупная выборка была разделена на основную и контрольную. В основную выборку $\left(\mathrm{N}_{\text {осн. }}\right)$ были включены 65 военных пенсионеров. В контрольную выборку $\left(\mathrm{N}_{\text {контр. }}\right)$, сформированную для сравнения исследуемых личностных характеристик, вошли 65 гражданских пенсионеров.

Гендерные показатели основной выборки представлены соотношением долей: мужчины-89,2\% (58 человек), женщины - 10,8\% (7 человек). В контрольной выборке: мужчины86,2\% (56 человек), женщины-13,8\% (9 человек).

Средний возраст респондентов в основной выборке составляет $62,09 \pm 10,4$ года, в контрольной выборке $-61,11 \pm 9,2$ год.

Среди военных пенсионеров в настоящее время работают $40 \%$ респондентов (26 человек). Доля неработающих военных пенсионеров составляет 60 \% (39 человек). В гражданской выборке доля работающих пенсионеров составляет 27,7\% (18 человек), неработающих пенсионеров - 72,3\% (47 человек).

Первичные описательные характеристики статистики основной и контрольной выборок по возрасту представлены в таблице 1.

Для достижения цели исследования были использованы следующие диагностические инструменты:

Методика Ш. Швариа для изучения доминирующих иенностей личности. Ш. Шварц исходил из того, что наиболее существенным содержательным аспектом, лежащим в основе различий между ценностями, выступает тип мотивационных целей, которые они выражают. Поэтому он сгруппировал отдельные ценности в типы ценностей в соответствии с общностью их целей. В результате были описаны десять базовых мотивационно отличающихся типов, соответственно их центральной цели (Карандашев, 2004; Schwartz, 1992). 
ЛАВРОВА О. А.

СОДЕРЖАНИЕ ПРИОРИТЕТНЫХ ЦЕННОСТЕЙ У ВОЕННЫХ И ГРАЖДАНСКИХ ПЕНСИОНЕРОВ...

РосСиЙский психологИчЕСКИй жУРнАл, 2019, Т. 16, № 4, 42-55. doi: 10.21702/rpj.2019.4.4

ОБЩАЯ ПСИХОЛОГИЯ, ПСИхОЛОГИЯ ЛИЧНОСТИ, ИСТОРИЯ ПСИХОЛОГИИ

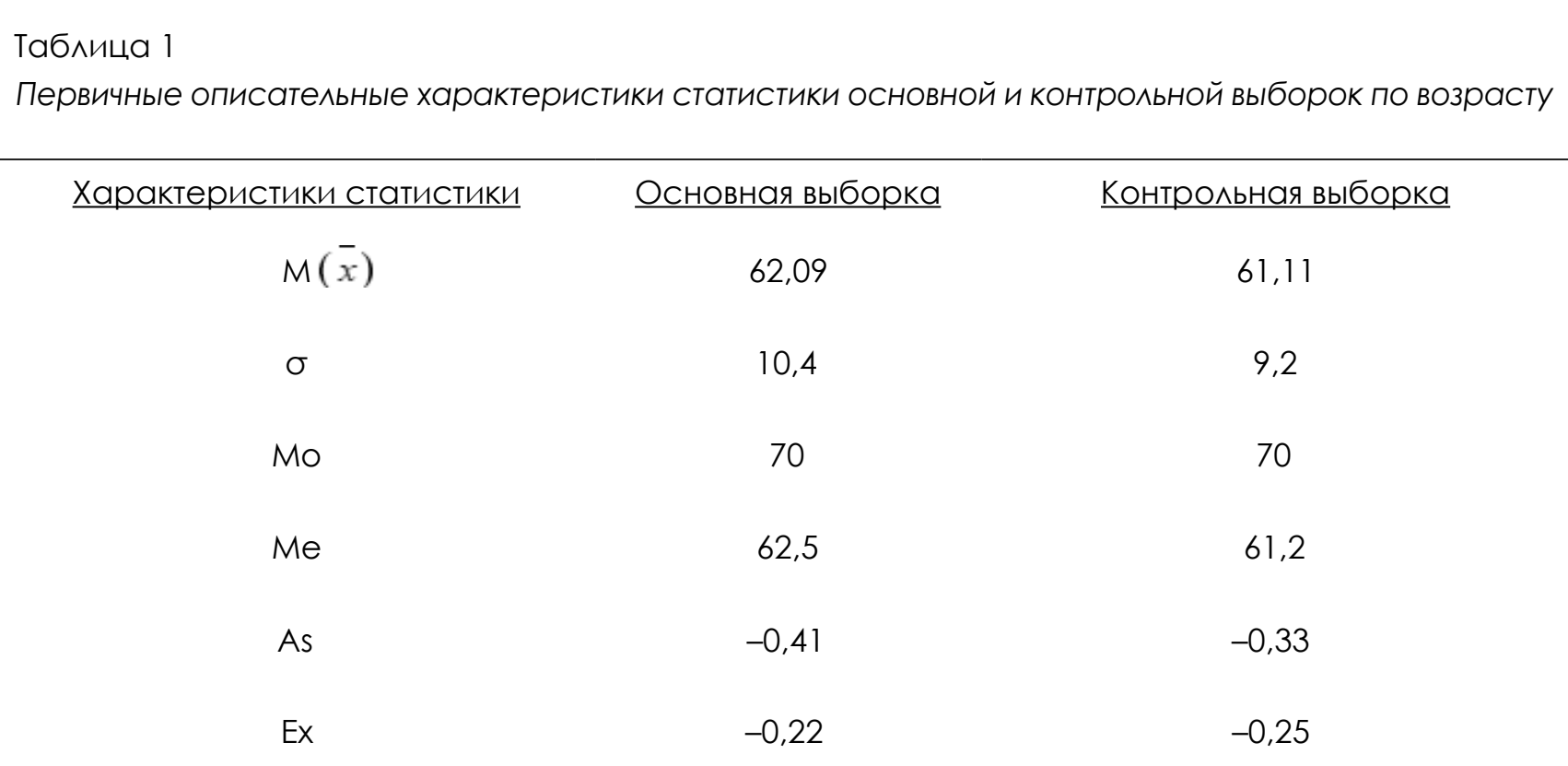

Для каждого испытуемого, в соответствии с авторской методикой, рассчитывался средний балл по двум ее частям («Обзор ценностей» и «Профиль личности»). В соответствии со средним баллом по каждому типу ценностей устанавливалось их рейтинговое соотношение. Каждому типу ценностей присваивался ранг от 1 до 10. Минимальный ранг (10) получали те ценности, которые набрали наиболее высокий средний балл. Максимальный ранг (1), соответственно,те ценности, по которым был получен самый низкий средний балл. В соответствии с авторской интерпретацией, те ценности, которые получили наиболее высокие ранги (от 1 до 3), имеют наиболее высокую значимость для испытуемого. Ценности, имеющие ранги от 7 до 10, минимально значимы для испытуемого (Карандашев, 2004).

Уровни самоактуализации респондентов диагностировались с помощью краткой шкалы измерения самоактуализации (Хьелл и Зиглер, 2003; Jones \& Crandall, 1986). Шкала состоит из 15-ти утверждений. Авторами опросника была подтверждена положительная корреляция полученного в ходе применения Краткой шкалы индекса самоактуализации со всеми значениями «Опросника личной ориентации» (Personal Orientation Inventory, POI), разработанного для оценки различных характеристик самоактуализации в соответствии с концепцией А. Маслоу. Шкала позволяет дифференцировать уровень самоактуализации респондентов как высокий, средний или низкий.

Статистический анализ полученных эмпирических данных проводился с применением компьютерной статистической программы IBM SPSS Statistics 25.

\section{Результаты и их обсуждение}

На первом этапе исследования была проведена диагностика индивидуальных ценностей респондентов в основной и контрольной выборках с применением опросника Ш. Шварца (см. табл. 2 и 3). 
ЛАВРОВА О. А.

СОДЕРЖАНИЕ ПРИОРИТЕТНЫХ ЦЕННОСТЕЙ У ВОЕННЫХ И ГРАЖДАНСКИХ ПЕНСИОНЕРОВ..

РОССИЙСКИЙ пСИХОЛОГИЧЕСКИЙ ЖУРнАл, 2019, Т. 16, № 4, 42-55. doi: 10.21702/rpj.2019.4.4

ОБЩАЯ ПСИХОЛОГИЯ, ПСИХОЛОГИЯ ЛИЧНОСТИ, ИСТОРИЯ ПСИХОЛОГИИ

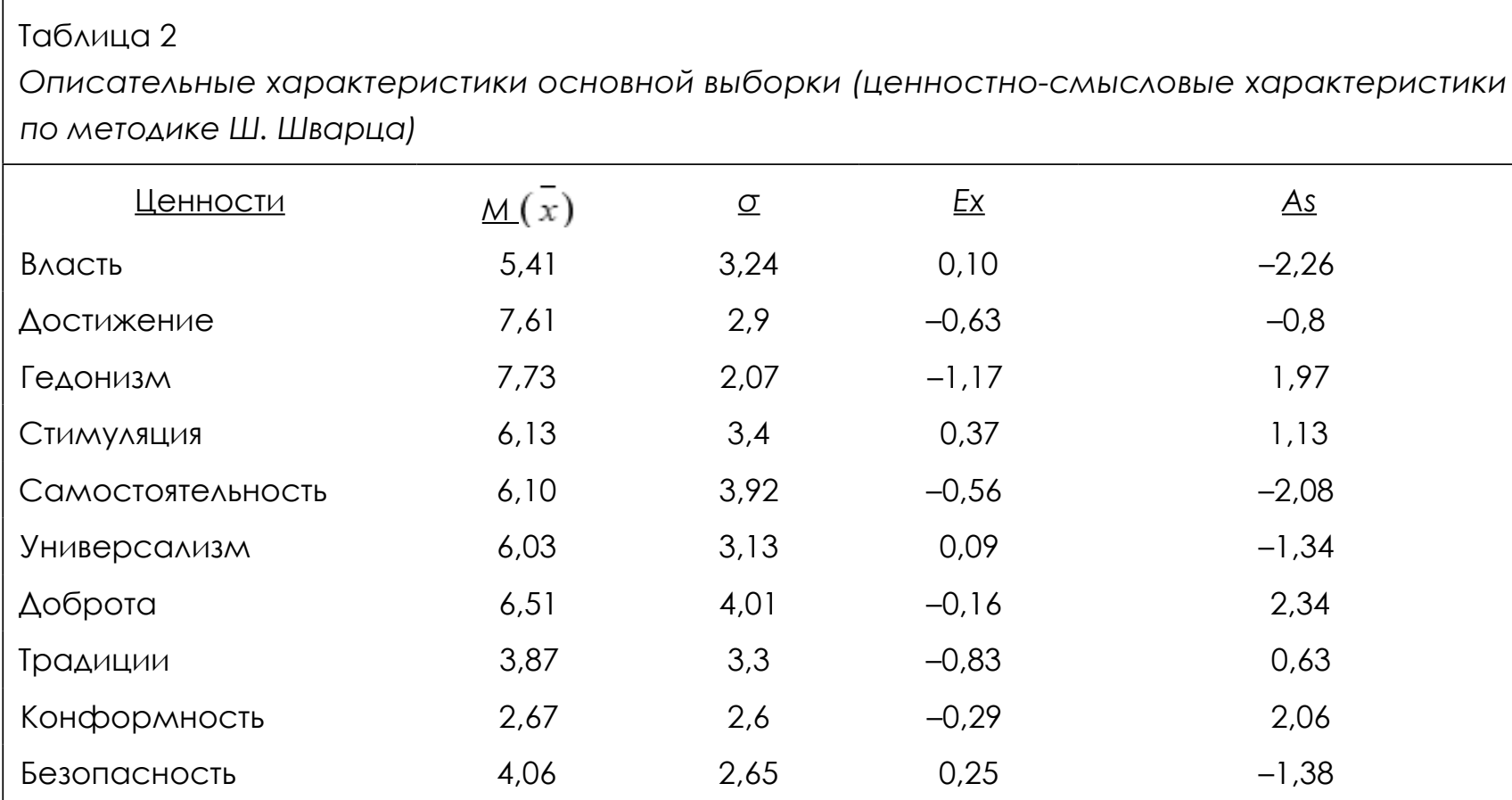

\section{Таблица 3}

Описательные характеристики контрольной выборки (ценностно-смысловые характеристики по метолике Ш. Шварца)

\begin{tabular}{|lcccc|}
\hline \multicolumn{1}{r}{ Ценности } & $\underline{M}(\bar{x})$ & $\underline{\sigma}$ & $\underline{\underline{ }}$ & $\underline{\text { As }}$ \\
Власть & 6,83 & 2,33 & 0,21 & $-2,44$ \\
Аостижение & 6,26 & 3,01 & $-0,67$ & 0,92 \\
Гелонизм & 7,01 & 3,76 & $-1,43$ & 2,16 \\
Стимуляция & 5,27 & 2,07 & $-1,65$ & 1,55 \\
Самостоятельность & 6,48 & 3,01 & 0,39 & $-1,93$ \\
Универсализм & 4,63 & 3,88 & 0,99 & $-1,72$ \\
Аоброта & 4,22 & 2,5 & 0,49 & $-2,84$ \\
Традиции & 5,99 & 4,12 & $-0,95$ & $-0,87$ \\
Конорормность & 5,43 & 3,75 & $-0,39$ & 2,33 \\
Безопасность & 5,19 & 2,98 & 0,65 & $-1,19$ \\
\hline
\end{tabular}

Для каждой выборки с учетом среднеранговых значений был определен рейтинг ценностей, и проведено их сравнение (данные представлены в таблице 4). 
ЛАВРОВА О. А.

СОДЕРЖАНИЕ ПРИОРИТЕТНЫХ ЦЕННОСТЕЙ У ВОЕННЫХ И ГРАЖДАНСКИХ ПЕНСИОНЕРОВ...

Российский психологИчЕСкий жУРнАл, 2019, Т. 16, № 4, 42-55. doi: 10.21702/rpj.2019.4.4

ОБЩАЯ ПСИХОЛОГИЯ, ПСИхОЛОГИЯ лИЧнОстИ, ИСТОРИя ПСИхОЛОГИИ

\begin{tabular}{|c|c|c|c|c|c|c|}
\hline \multirow{2}{*}{ Ценности } & \multicolumn{2}{|c|}{$\frac{\text { Военные }}{\text { пенсионеры }}$} & \multicolumn{2}{|c|}{$\begin{array}{l}\text { Гражланские } \\
\text { пенсионеры }\end{array}$} & \multirow[b]{2}{*}{$t_{\text {эмп. }}$} & \multirow{2}{*}{$\begin{array}{c}\text { Аостоверность } \\
\text { различий }\end{array}$} \\
\hline & $M(\bar{x})$ & $\begin{array}{l}\text { Рейтинг } \\
\text { (ранг) }\end{array}$ & $M(\bar{x})$ & $\begin{array}{l}\text { Рейтинг } \\
\text { (ранг) }\end{array}$ & & \\
\hline В^асть & 5,41 & 4 & 6,83 & 9 & 3,99 & $p \leq 0,01$ \\
\hline Аостижение & 7,61 & 9 & 6,26 & 7 & 3,06 & $p \leq 0,01$ \\
\hline ГеАонизм & 7,73 & 10 & 7,01 & 10 & 0,65 & недостоверны \\
\hline Стимуляция & 6,13 & 7 & 5,27 & 4 & 3,13 & $p \leq 0,01$ \\
\hline Самостоятельность & 6,10 & 6 & 6,48 & 8 & 0,99 & недостоверны \\
\hline Универсализм & 6,03 & 5 & 4,63 & 2 & 2,97 & $p \leq 0,01$ \\
\hline Аоброта & 6,51 & 8 & 4,22 & 1 & 3,06 & $p \leq 0,01$ \\
\hline Тралиции & 3,87 & 2 & 5,99 & 6 & 2,54 & $p \leq 0,05$ \\
\hline Конфрормность & 2,67 & 1 & 5,43 & 5 & 2,29 & $p \leq 0,05$ \\
\hline Безопасность & 4,06 & 3 & 5,19 & 3 & 1,33 & недостоверны \\
\hline
\end{tabular}

Разброс среднеранговых значений в группе военных пенсионеров от 7,73 до 2,67.

Высокую значимость для испытуемых - военных пенсионеров (1-3 значения в рейтинге) имеют следующие ценности:

1. Конформность (Conformity). Определяющая мотивационная цель этого типа - сдерживание и предотвращение действий, а также склонностей и побуждений к действиям, которые могут причинить вред другим или не соответствуют социальным ожиданиям. Данная ценность является производной от требования сдерживать склонности, имеющие негативные социальные последствия (послушание, самодисциплина) (Карандашев, 2004).

2. Tрадиции (Tradition). Любые социальные группы вырабатывают свои символы и ритуалы, которые закрепляются в традициях и обычаях. Традиционный способ поведения становится символом групповой солидарности, выражением единых ценностей. Традиции реализуются через принятие и следование определенным нормам поведения. Мотивационная цель данной ценности - уважение, принятие обычаев, уважение традиций и следование им (Карандашев, 2004).

3. Безопасность (Security). Мотивационная цель этого типа - безопасность для других людей и себя, стабильность общества и взаимоотношений. По мнению Ш. Шварца, существует один обобщенный тип ценности «безопасность»-ценности, относящиеся к коллективной безопасности, в значительной степени выражают цель безопасности и для личности (социальный порядок, безопасность семьи, национальная безопасность, чувство принадлежности, здоровье) (Карандашев, 2004). 
ЛАВРОВА О. А.

СОДЕРЖАНИЕ ПРИОРИТЕТНЫХ ЦЕННОСТЕЙ У ВОЕННЫХ И ГРАЖДАНСКИХ ПЕНСИОНЕРОВ..

РОССИЙСКИЙ пСИХОЛОГИЧЕСКИЙ ЖУРнАл, 2019, Т. 16, № 4, 42-55. doi: 10.21702/rpj.2019.4.4

ОБЩАЯ ПСИХОЛОГИЯ, ПСИХОЛОГИЯ ЛИЧНОСТИ, ИСТОРИЯ ПСИХОЛОГИИ

Наименьшая значимость (7-10 значения в рейтинге) диагностирована для таких ценностей, как стимуляция, доброта, достижение, гедонизм.

В контрольной выборке отмечен меньший разброс среднеранговых значений диагностируемых ценностей - от 6,99 до 4,22. Это позволяет предположить большую дифференциацию индивидуальных ценностных выборов среди гражданских пенсионеров.

Высокую значимость для респондентов в контрольной выборке (1-3 строки в рейтинге) имеют такие ценности, как:

1. Доброта (Benevolence). Это более узкий «просоциальный» тип ценностей, сфокусированный на благополучии в повседневном взаимодействии с близкими людьми. Этот тип ценностей считается производным от потребности в позитивном взаимодействии, потребности в аффилиации. Его мотивационная цель - сохранение благополучия людей, с которыми индивид находится в личных контактах (полезность, снисходительность, честность, ответственность, дружба, зрелая любовь) (Карандашев, 2004).

2. Универсализм (Universalism). Мотивационная цель данного типа ценностей-понимание, терпимость, защита благополучия. Мотивационные цели универсализма производны от тех потребностей выживания групп и индивидов, которые становятся явно необходимыми при вступлении людей в контакт с кем-либо вне своей среды или при расширении первичной группы (Карандашев, 2004).

3. Безопасность (Security).

Наименьшую значимость для респондентов в контрольной выборке (7-10 в рейтинге ценностей) имеют такие ценности, как достижение, самостоятельность, власть и гедонизм (Карандашев, 2004).

Было проведено сравнение двух выборок по каждой из диагностируемых ценностей на предмет достоверности различий с применением статистического t-критерия Стьюдента. Статистическая достоверность различий между сравниваемыми выборками подтверждена по таким ценностям, как власть, достижение, стимуляция, универсализм, доброта, традиции, конформность. Более высокие рейтинги и, соответственно, более высокую значимость в группе военных пенсионеров (по сравнению с гражданскими) имеют такие ценности, как власть ( $p \leq 0,01)$, традиции ( $\leq \leq 0,05)$. По таким ценностям, как достижение, стимуляция, универсализм и доброта, более высокие рейтинги зафиксированы в контрольной выборке, что говорит об их большей значимости для гражданских пенсионеров, по сравнению с военными.

Результаты диагностики с применением краткой шкалы самоактуализации позволили отметить в обеих выборках представленность испытуемых с разными уровнями самоактуализации. В основной выборке среди военных пенсионеров высокий уровень отмечен у 18,4\% респондентов (12 человек). Средний уровень самоактуализации диагностирован у 50,8\% респондентов (33 человека), низкий уровень самоактуализации отмечен у 30,8\% респондентов (20 человек). В контрольной выборке высокий уровень самоактуализации имеют 16,9\% гражданских пенсионеров (11 человек). Средний уровень самоактуализации зафиксирован у 44,6\% респондентов (29 человек). Низкий уровень диагностирован у 38,5 \% испытуемых (25 человек).

Проведенная с применением методов параметрической статистики (критерия углового преобразования Фишера, $\varphi^{*}$ ) проверка не выявила достоверных различий между выборками по данному показателю. Распределение респондентов в основной и контрольной выборках по уровням самоактуализации не имеет выраженной специфики, связанной с особенностями их пенсионного статуса. 
ЛАВРОВА О. А.

СОДЕРЖАНИЕ ПРИОРИТЕТНЫХ ЦЕННОСТЕЙ У ВОЕННЫХ И ГРАЖДАНСКИХ ПЕНСИОНЕРОВ...

РосСиЙский психологИчЕСКИй жУРнАл, 2019, Т. 16, № 4, 42-55. doi: 10.21702/rpj.2019.4.4

ОБЩАЯ ПСИХОЛОГИЯ, ПСИхОЛОГИЯ лИЧнОстИ, ИСТОРИя ПСИхОЛОГИИ

Было проведено сравнение ценностных приоритетов у респондентов с разными уровнями самоактуализации в обеих выборках. В группе военных пенсионеров с высоким уровнем самоактуализации наиболее значимой ценностью выступает самостоятельность $(\mathrm{M}(\bar{x})=2,07)$. Для респондентов с низким уровнем самоактуализации максимальные рейтинги имеют такие ценности, как власть (M $(\bar{x})=4,12)$ и стимуляция $(\mathrm{M}(\bar{x})=4,65)$. Данные представлены в таблице 5.

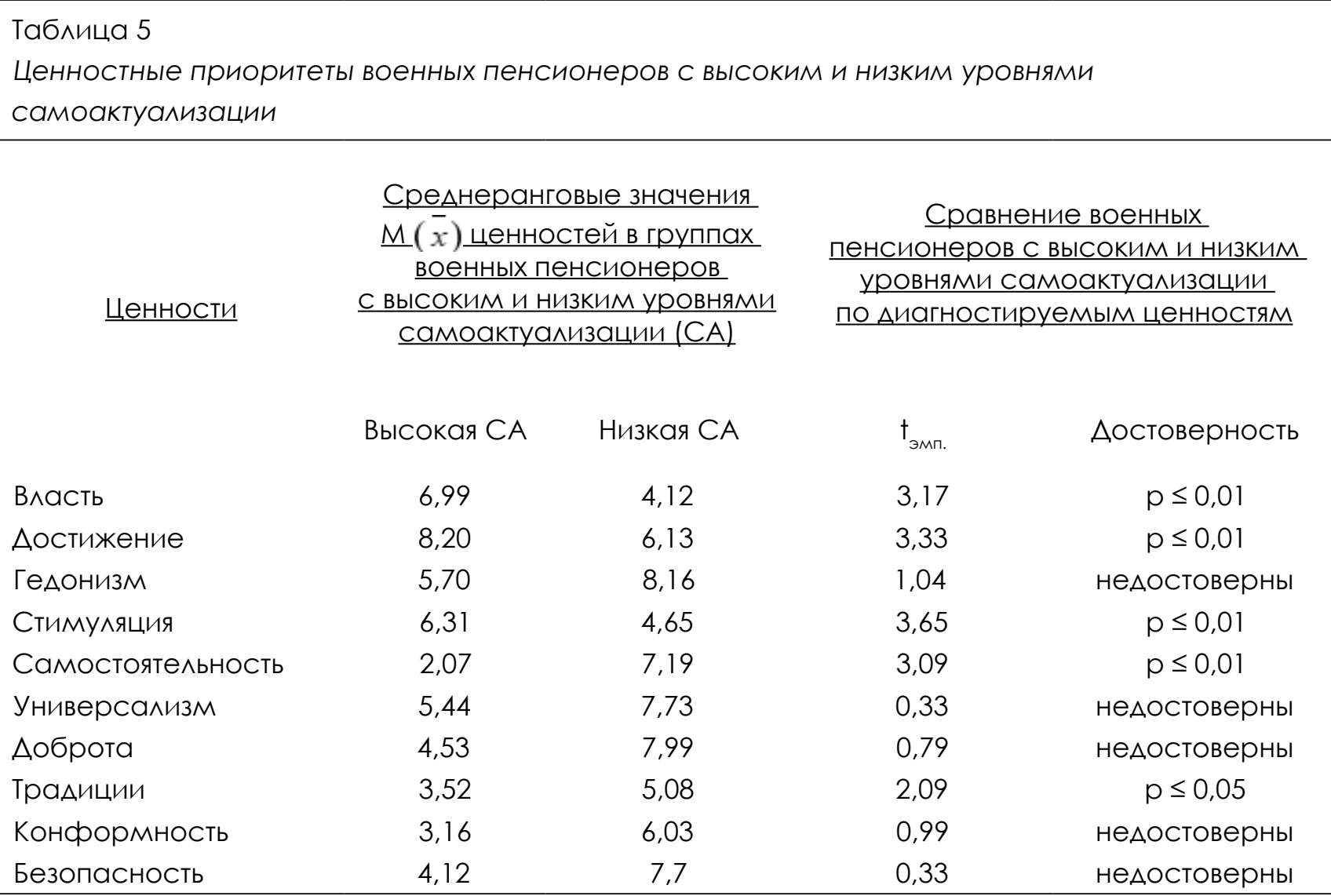

Статистическая достоверность различий между сравниваемыми группами подтверждена по таким ценностям, как власть, достижение, стимуляция. Данные ценности являются более значимыми для респондентов с низким уровнем самоактуализации. Также подтверждена статистическая достоверность различий между сравниваемыми группами по таким ценностям, как самостоятельность и традиции, которые, наоборот, являются более значимыми для респондентов с высоким уровнем самоактуализации.

В качестве ценностных приоритетов для гражданских респондентов с высоким уровнем самоактуализации выступают самостоятельность $(\mathrm{M}(\bar{x})=3,0)$ и доброта $(\mathrm{M}(\bar{x})=4,12)$. Для группы гражданских пенсионеров с низким уровнем самоактуализации в качестве ценностных приоритетов выступают достижение $(\mathrm{M}(x)=3,01)$, власть $(\mathrm{M}(\bar{x})=4,27)$ и стимуляция $(\mathrm{M}(\bar{x})=4,35)$. Данные представлены в таблице 6. 
ЛАВРОВА О. А.

СОДЕРЖАНИЕ ПРИОРИТЕТНЫХ ЦЕННОСТЕЙ У ВОЕННЫХ И ГРАЖДАНСКИХ ПЕНСИОНЕРОВ..

РОССИЙСКИЙ пСИХОЛОГИЧЕСКИЙ ЖУРнАл, 2019, Т. 16, № 4, 42-55. doi: 10.21702/rpj.2019.4.4

ОБЩАЯ ПСИХОЛОГИЯ, ПСИХОЛОГИЯ ЛИЧНОСТИ, ИСТОРИЯ ПСИХОЛОГИИ

\begin{tabular}{|c|c|c|c|c|}
\hline \multirow{5}{*}{ Ценности } & \multirow{4}{*}{\multicolumn{2}{|c|}{$\begin{array}{l}\frac{\text { Среднеранговые значения }}{M(\bar{x}) \text { ценностей в группах }} \\
\frac{\text { гражАанских пенсионеров }}{\text { с высоким и низким уровнями }} \\
\frac{\text { самоактуализации (СА) }}{\text { вало }}\end{array}$}} & \multirow{4}{*}{\multicolumn{2}{|c|}{$\begin{array}{c}\frac{\text { Сравнение гражданских }}{\frac{\text { пенсионеров с высоким }}{\text { и низким уровнями }}} \\
\frac{\text { самоактуализации }}{\text { по диагоостируемым ценностям }}\end{array}$}} \\
\hline & & & & \\
\hline & & & & \\
\hline & & & & \\
\hline & Высокая CA & Низкая СА & $t_{\text {эмп. }}$ & Аостоверность \\
\hline В^асть & 8,14 & 4,27 & 3,75 & $p \leq 0,01$ \\
\hline Аостижение & 8,01 & 3,01 & 3,76 & $p \leq 0,01$ \\
\hline ГеАонизм & 6,99 & 7,98 & 0,97 & неАостоверны \\
\hline Стимуляция & 6,42 & 4,35 & 2,71 & $p \leq 0,05$ \\
\hline Самостоятельность & 3,0 & 7,98 & 3,42 & $p \leq 0,01$ \\
\hline Универсализм & 4,39 & 5,07 & 1,55 & неАостоверны \\
\hline Аоброта & 4,12 & 5,43 & 2,68 & $p \leq 0,05$ \\
\hline Тралиции & 5,9 & 7,54 & 1,12 & недостоверны \\
\hline Конорормность & 6,01 & 5,22 & 1,99 & недостоверны \\
\hline Безопасность & 5,44 & 6,38 & 1,63 & недостоверны \\
\hline
\end{tabular}

Проведенное статистическое сравнение между группами с высоким и низким уровнями самоактуализации выявило достоверность различий по таким ценностям, как власть, достижение, стимуляция, которые являются доминирующими в группе респондентов с низким уровнем самоактуализации. Также значимые различия между группами отмечены по таким ценностным приоритетам, как доброта и самостоятельность, которые имеют большую выраженность в группе гражданских респондентов с высоким уровнем самоактуализации.

Проведенный анализ и сравнения выявили сходство военных и гражданских пенсионеров с высоким уровнем самоактуализации по такому ценностному приоритету, как самостоятельность. Ценностными приоритетами и военных и гражданских респондентов с низким уровнем самоактуализации выступают власть и стимуляция. Данный вывод подтвержден статистическим сравнением ценностных рядов у военных и гражданских респондентов с одинаковым уровнем самоактуализации (табл. 7). Достоверные различия между сравниваемыми группами отмечены только по отдельным диагностируемым ценностям. В группе с высоким уровнем самоактуализации это доброта и универсализм, которые имеют более высокий уровень значимости у гражданских пенсионеров. В группе с низким уровнем самоактуализации это самостоятельность и традиции, которые являются более значимыми ценностями для военных пенсионеров. 
ЛАВРОВА О. А.

СОДЕРЖАНИЕ ПРИОРИТЕТНЫХ ЦЕННОСТЕЙ У ВОЕННЫХ И ГРАЖДАНСКИХ ПЕНСИОНЕРОВ...

РосСиЙский психологИчЕСКИй жУРнАл, 2019, Т. 16, № 4, 42-55. doi: 10.21702/rpj.2019.4.4

ОБЩАЯ ПСИХОЛОГИЯ, ПСИхОЛОГИЯ ЛИЧНОСТИ, ИСТОРИЯ ПСИХОЛОГИИ

\begin{tabular}{|c|c|c|c|c|}
\hline \multicolumn{5}{|c|}{$\begin{array}{l}\text { Таблица } 7 \\
\text { Результаты статистического сравнения военных и гражАанских г } \\
\text { уровнями самоактуализации по Аиагностируемым ценностям }\end{array}$} \\
\hline \multirow{6}{*}{ Ценности } & \multirow{5}{*}{\multicolumn{2}{|c|}{$\begin{array}{c}\text { Сравнение военных } \\
\frac{\text { и гражданских пенсионеров }}{\text { с высоким уровнем }} \\
\frac{\text { самоактуализации }}{\text { по диагностируемым ценностям }}\end{array}$}} & \multirow{2}{*}{\multicolumn{2}{|c|}{ 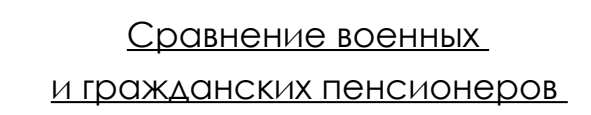 }} \\
\hline & & & & \\
\hline & & & \multicolumn{2}{|c|}{ с низким уровнем } \\
\hline & & & \multirow{2}{*}{\multicolumn{2}{|c|}{$\begin{array}{c}\text { самоактуализации } \\
\text { по Аиагностируемым ценностям }\end{array}$}} \\
\hline & & & & \\
\hline & $\dagger_{\text {эмп. }}$ & Аостоверность & $\dagger_{\text {эмп. }}$ & Аостоверность \\
\hline В^асть & 1,23 & недостоверны & 0,12 & неАостоверны \\
\hline Аостижение & 1,12 & недостоверны & 0,74 & недостоверны \\
\hline ГеАонизм & 0,23 & недостоверны & 1,56 & недостоверны \\
\hline Стимуляция & 0,67 & недостоверны & 0,33 & недостоверны \\
\hline Самостоятельность & 0,99 & недостоверны & 2,07 & $p \leq 0,05$ \\
\hline Универсализм & 2,42 & $p \leq 0,05$ & 1,42 & недостоверны \\
\hline Аоброта & 3,04 & $p \leq 0,01$ & 1,29 & недостоверны \\
\hline Тралиции & 1,23 & недостоверны & 2,16 & $p \leq 0,05$ \\
\hline Конорормность & 1,98 & недостоверны & 1,23 & недостоверны \\
\hline Безопасность & 0,33 & недостоверны & 1,96 & недостоверны \\
\hline
\end{tabular}

\section{Выводы}

Проведенный теоретический анализ позволил обосновать изучение характеристик ценностно-смысловой сферы пенсионера как компонентов структуры его адаптационной готовности к значительным жизненным изменениям в данный период жизни. В контексте субъектного подхода также обосновано рассмотрение уровня самоактуализации пенсионера как одного из критериев его адаптационной готовности к изменениям в социальном статусе.

Проведенный анализ эмпирических данных дает основание говорить об определенной специфике ценностных приоритетов военных пенсионеров, которая может быть обусловлена особенностями их предшествующего жизненного и профессионального опыта, по сравнению с гражданскими пенсионерами. Определенное сходство жизненных и профессиональных условий в период прохождения военной службы определяет большую однородность военных пенсионеров как социальной группы, по сравнению с гражданскими пенсионерами, и формирует ее более отчетливые ценностные приоритеты. Таковыми, по данным нашего исследования, выступают конформность, традиции и безопасность.

Отмечено, что ценностно-смысловыми приоритетами пенсионеров с высоким уровнем самоактуализации, независимо от статуса, выступают самостоятельность мышления и выбора способов действия, способность к самоконтролю и самоуправлению. 
ЛАВРОВА О. А.

СОДЕРЖАНИЕ ПРИОРИТЕТНЫХ ЦЕННОСТЕЙ У ВОЕННЫХ И ГРАЖДАНСКИХ ПЕНСИОНЕРОВ..

РОССИЙСКИЙ пСИХОЛОГИЧЕСКИЙ ЖУРнАл, 2019, Т. 16, № 4, 42-55. doi: 10.21702/rpj.2019.4.4

ОБЩАЯ ПСИХОЛОГИЯ, ПСИХОЛОГИЯ ЛИЧНОСТИ, ИСТОРИЯ ПСИХОЛОГИИ

Стремление к достижению высокого социального статуса или престижа, контролю или доминированию, стремление к новизне и глубоким переживаниям выступают ценностно-смысловыми приоритетами как у военных, так и у гражданских пенсионеров с низким уровнем самоактуализации. Очевидно, это связано с ограниченными возможностями фактической реализации данных ценностных приоритетов в пенсионный период.

Основной областью практического приложения полученных в ходе исследования результатов может стать их применение в программах психологического сопровождения военнослужащих, с целью формирования их адаптационной готовности к изменившимся условиям жизни при выходе на пенсию. Выделенные в рамках исследования ценностно-смысловые компоненты адаптационной готовности могут служить ориентирами в психологической работе с военнослужащими.

Несомненно, представленные результаты можно рассматривать в качестве промежуточных, а их интерпретация обусловливает постановку вопросов для следующего этапа исследования. В частности, целесообразно на большем объеме эмпирической выборки проанализировать особенности ценностно-смысловой сферы пенсионеров с учетом их гендерных и возрастных характеристик, особенностей предшествующего выходу на пенсию профессионального опыта, а также ряда особенностей актуального статуса пенсионеров, и обосновать их роль в формировании адаптационной готовности.

\section{Литература}

Анцыферова, Л. И. (2006). Развитие личности и проблемы геронтопсихологии: монография (2-е изд., испр. и доп.). Москва: Институт психологии РАН.

Арендачук, И. В. (2013). Адаптационная готовность личности к учебно-профессиональной деятельности: системно-диахронический подход. Современные исследования социальных проблем (электронный научный журнал), 10(30). doi: 10.12731/2218-7405-2013-10-27

Вызулина, К. С. и Ясько, Б. А. (2015). Личностные детерминанты социально-психологической адаптации личности: теоретико-методологические основы исследования. Вестник Адыгейского государственного университета. Серия 3: Педагогика и психология, 1(157). Доступ 15 Ноября 2019, источник https://cyberleninka.ru/article/n/lichnostnye-determinantysotsialno-psihologicheskoy-adaptatsii-lichnosti-teoretiko-metodologicheskie-osnovyissledovaniya

Григорьева, М. В. (2014). Понятийный аппарат психологии адаптации личности. Известия Саратовского ун-та. Новая серия. Серия Акмеология образования. Психология развития, 3(3), 259-262.

Елишев, С. О. (2010). Теоретико-методологические подходы к изучению понятий «ценность», «ценностные ориентации». Вестник Московского университета. Серия 18. Социология и политология, 3, 74-90.

Ермолаева, М. (2002). Практическая психология старости. Москва: ЭКСМО-Пресс.

Карандашев, В.Н.(2004). Методика Швариа для изучения ценностей личности: концепция и методическое руководство. Санкт-Петербург: Речь.

Ковалева, Н. Г. (н. д.). Дифференцированный подход к изучению потребностей и ценностных ориентаций пожилых. Сборник статей по социальной геронтологии. Доступ 21 Октября 2019, источник https://lib.uni-dubna.ru/search/files/sr sbornic/ sr sbornic.htm\#5

Куруленко, Э. А. (н. д.). Ценности женщин третьего возраста. Сборник статей по социальной 
ЛАВРОВА О. А.

СОДЕРЖАНИЕ ПРИОРИТЕТНЫХ ЦЕННОСТЕЙ У ВОЕННЫХ И ГРАЖДАНСКИХ ПЕНСИОНЕРОВ...

Российский психологИчЕСКИй жУРнАл, 2019, Т. 16, № 4, 42-55. doi: 10.21702/rpj.2019.4.4

ОБЩАЯ ПСИХОЛОГИЯ, ПСИхОЛОГИЯ лИЧнОстИ, ИСТОРИя ПСИхОЛОГИИ

геронтологии. Доступ 21 Октября 2019, источник https://lib.uni-dubna.ru/search/files/ sr sbornic/ sr sbornic.htm\#5

Леонтьев, Д. А. (1996). От социальных ценностей к личностным: социогенез и феноменология ценностной регуляции деятельности. Вестник Московского университета. Серия 14: Психология, 4, 35-44.

Мандель, Б. Р. (2015). Психология развития: Полный курс (иллюстрированное учебное пособие для студентов всех уровней обучения в высших учебных заведениях). Москва; Берлин: Директ-Медиа.

Рубинштейн, С. Л. (2003). Бытие и сознание. Человек и мир. Санкт-Петербург: Питер.

Сахарова, Т. Н., Уманская, Е. Г. и Цветкова, Н. А. (2016). Геронтопсихология. Учебник. Москва: Изд-во Московского педагогического государственного университета.

Соколова, В. Ф. и Берецкая, Е. А. (2017). Теория и практика реабилитации граждан пожилого возраста. Москва: Флинта.

Стюарт-Гамильтон, Я. (2010). Психология старения. Санкт-Петербург: Питер.

Халина, Н. В. (2009). Ценностные ориентации людей пожилого возраста и их представление о ценностных ориентациях значимых других. Известия Российского государственного педагогического университета им. А. И. Герцена, 102, 408-411.

Халфина, Р. Р. (2018). Выход на пенсию как психологическая проблема. В М. В. Нухова и др. (ред.), Человек в условиях социальных изменений: Сборник научных статей очной Международной научно-практической конференции (с. 133-136). Уфа: Изд-во Башкирского государственного педагогического университета им. М. Акмуллы.

Хмелькова, О. В. (2017). Структурные компоненты адаптационной готовности и психолого-педагогические условия ее формирования: динамический аспект. Интернет-журнал «Мир науки», 5(5). Доступ 05 Декабря 2019, источник https://mir-nauki.com/PDF/25PSMN517.pdf

Хьелл, Л. и Зиглер, Д. (2003). Теории личности (3-е изд.). Санкт-Петербург: Питер.

Шамионов, Р. М. (2015). Адаптационная готовность личности - субъекта социального взаимодействия. Известия Саратовского университета. Новая Серия. Философия. Психология. Педагогика, 15(4), 106-112. doi: 10.18500/1819-7671-2015-15-4-106-112

Bilsky, W., \& Schwartz, S. H. (1994). Values and personality. European Journal of Personality, 8(3), 163-181. doi: 10.1002/per.2410080303

Borg, I., Hertel, G., \& Hermann, D. (2017). Age and personal values: Similar value circles with shifting priorities. Psychology and Aging, 32(7), 636-641. doi: 10.1037/pag0000196

Jones, A., \& Crandall, R. (1986). Validation of a short index of self-actualization. Personality and Social Psychology Bulletin, 12(1), 63-73. doi: 10.1177/0146167286121007

Jones, C., Peskin, H., Wandeler, C., \& Woods, D. (2019). Culturally gendered personality traits across the adult lifespan: Longitudinal findings from two cohorts of the intergenerational studies. Psychology and Aging, 34(8), 1124-1133. doi: 10.1037/pag0000383

Juang, C., Knight, B. G., Carlson, M., Schepens Niemiec, S. L., Vigen, C., \& Clark, F. (2018). Understanding the mechanisms of change in a lifestyle intervention for older adults. The Gerontologist, 58(2), 353-361. doi: 10.1093/geront/gnw152

Kleineidam, L., Thoma, M. V, Maercker, A., Bickel, H., Mösch, E., Hajek, A., ... Wagner, M. (2019). What is successful aging? A psychometric validation study of different construct definitions. The Gerontologist, 59(4), 738-748. doi: 10.1093/geront/gny083

Löckenhoff, C. E., \& Rutt, J. L. (2017). Age differences in self-continuity: Converging evidence and directions for future research. The Gerontologist, 57(3), 396-408. doi: 10.1093/geront/gnx010 
Nikitin, J., \& Freund, A. M. (2019). The adaptation process of aging. In R. Fernández-Ballesteros, A. Benetos, \& J.-M. Robine (Eds.), The Cambridge Handbook of Successful Aging (pp. 281-298). Cambridge University Press. doi: 10.1017/9781316677018.018

Schwartz, S. H. (1992). Universals in the content and structure of values: Theory and empirical tests in 20 countries. Advances in Experimental Social Psychology, 25, 1-65. doi: 10.1016/ S0065-2601(08)60281-6

Stawski, R. S., Scott, S. B., Zawadzki, M. J., Sliwinski, M. J., Marcusson-Clavertz, D., Kim, J., ... Joshua, M. (2019). Age differences in everyday stressor-related negative affect: A coordinated analysis. Psychology and Aging, 34(1), 91-105. doi: 10.1037/pag0000309

Teshale, S. M., \& Lachman, M. E. (2016). Managing daily happiness: The relationship between selection, optimization, and compensation strategies and well-being in adulthood. Psychology and Aging, 31(7), 687-692. doi: 10.1037/pag0000132

Конфликт интересов отсутствует 